\title{
Knowledge of health professionals in transfusion and transfusion safety in Morocco.
}

Fatna EL Mehdaoui ${ }^{\mathbf{1}, \mathbf{2}}$. Abdelmajid Soulaymani ${ }^{1}$. Malika. EL Khiari ${ }^{\mathbf{3}}$. Soukaina Benissa Laghawati ${ }^{\mathbf{3}}$ and Raouf Alami $^{\mathbf{2}}$

1. Research Laboratory High Institute of Nursing Professions and Health Techniques (ISPITSR) of Rabat Morocco.

2. Biology and Health Laboratory, School of Sciences, Ibn Tofaïl University, Kenitra, Morocco.

3. Ibn Sina University Hospital of Rabat. Morocco.

\begin{abstract}
Introduction: Transfusion safety is a health issue of global concern. Despite improvements, every recipient may be exposed to immunologic or infectious transfusion events. Indeed, transfusion safety also depends on the knowledge and skills of health professionals in transfusion.

Objective: To evaluate the knowledge of transfusion and transfusion safety among health professionals.

Materials and method: 47 volunteers, working at the University Hospital Ibn Sina in Rabat of Morocco, answered a survey on knowledge, skills in transfusion and transfusion safety.

Results: $68 \%$ of the participants were female against $32 \%$ male, $85.11 \%$ were aged $20-30$ years. $77 \%$ had a seniority of less than 5 years. $57 \%$ were nurses and $42 \%$ doctors. According to these participants, allergic reactions and hyperthermia occur with $85.11 \%$ after a transfusion, $57.45 \%$ mentioned lung edema.

$80.85 \%$ of the participants stated that immunological and infectious risks are the main risks occurring after transfusion. $25.53 \%$ did not know that there were preventive measures for transfusion risks, $8.51 \%$ stated that there were none. $72.34 \%$ of the staff stated that hemovigilance is based on transfusion surveillance.

For $68.09 \%$ reporting transfusion events, informing recipients and monitoring them after transfusion are the main tools of hemovigilance. $27.66 \%$ of the participants were aware of the transfusion regulations and $53.19 \%$ were not. Only $41 \%$ had received training in blood transfusion. $91.49 \%$ of the participants wanted to develop their transfusion knowledge and competence.

Conclusion: Heterogeneity of knowledge and skills in transfusion is raised among these professionals, as well as a great motivation to improve their knowledge and the development of their skills in the field of transfusion. Thus, the development of training programs remains an urgent need for health professionals to further improve their knowledge and ensure the safety and quality of blood transfusions.
\end{abstract}

Key words: Blood transfusion, Transfusion risk, Health professional, Knowledge, Training.

\section{Introduction}

Transfusion safety is a health issue of great concern worldwide. Many measures have been used to eliminate or at least reduce the risk associated with the transfusion of blood products $[1,2]$. However, this risk persists and every recipient can be exposed to immunological or infectious transfusion accidents related mainly to bacterial contamination. Despite advances in microbiology that have documented the pathogens' transmission risk, and the development of transfusion practice, still persist the risk of infectious agents transmission. Transfusion of blood and blood products contaminated with bacteria is a public health issue that can have serious and even fatal consequences [3].

Vigilance is of paramount importance in transfusion medicine, and transfusion safety depends on many factors namely: new infections, silent stage of an infection, technical errors, lack or insufficient knowledge and skills in transfusion and transfusion safety among health professionals, and which may be the cause of the very important transfusion accidents in hospitals [4]. Previous studies have noted a lack of transfusion knowledge among health care practitioners $[5,6]$, the importance of this knowledge for the quality, and safety of transfusion requires its evaluation and verification. It is with this objective in mind that this study was carried out, in order to assess the knowledge of transfusion, and transfusion safety among health care professionals at the level of the Ibn Sina University Hospital of Rabat (CHUISR).

\section{Materials and Methods}

This study aimed to describe, and to evaluate the knowledge of health professionals, concerning blood transfusion practices and transfusion safety. The population of this study was 47 volunteer health professionals, who were working in medical A, medical B, and in the intensive care units of Ibn Sina University Hospital of Rabat Morocco. The required permission was obtained from the institution where the research was performed before the investigation was initiated. Study data were collected in May 2019.

The study inclusion criteria were as follows: working as health professionals in medical A, medical B and in the intensive care units chosen, and willing to participate in the study. All the participants were introduced to the aim of the study. Ethical principles were respected, confidentiality was guaranteed and verbal consent was obtained from the participants. Then, only participants who agreed to participate in this study were accepted. 
In this study some questions were prepared according to literature information, and used to collect the relevant data. The knowledge anonymous surveys are on four parts: The socio-demographic characteristics of the study participants as (age, sex, function...),

blood transfusion knowledge's, transfusion safety knowledge's (Key stages of transfusion therapy, risks, blood transfusion regulations and hemovigilance), and training and suggestions. To evaluate blood transfusion knowledge and safety the questions used generally were multiple choice questions, some of them were direct "yes or no" questions. The data collected by the questionnaire were classified and grouped in files and processed using Microsoft Excel software. Descriptive statistical methods (frequencies) were used to present study data, and qualitative data were compared to others studies results. All results were presented in the form of tables and graphs.

\section{Results}

A total of 47 health care professionals participating in our study responded to the question, $68 \%$ of the participants were female against 32\% male, $85,11 \%$ had an age between $20-30$ years and $15 \%$ between 31 40 years. $23 \%$ of these professionals had seniority between 6 and 10 years and $77 \%$ had a seniority not exceeding 5 years. In this study a majority of health professionals were nurses $57 \%$ and $42 \%$ were doctors (Table1).

Table1. Sociodemographic data of the participants.

\begin{tabular}{|c|c|}
\hline Participants $\quad(n=47)$ & Percent \% \\
\hline \multicolumn{2}{|l|}{ Gender } \\
\hline $\mathrm{F}$ & 68 \\
\hline M & 32 \\
\hline \multicolumn{2}{|l|}{ Age in years } \\
\hline $20-30$ & 85,11 \\
\hline $31-40$ & 14,89 \\
\hline $41-50$ & 00,00 \\
\hline $51-60$ & 00,00 \\
\hline \multicolumn{2}{|l|}{ Profile } \\
\hline Doctor & 42 \\
\hline Nurse & 57 \\
\hline \multicolumn{2}{|l|}{ Seniority in years } \\
\hline $1-5$ & 77,00 \\
\hline $6-10$ & 23,00 \\
\hline $11-20$ & 00,00 \\
\hline 21-more & 00,00 \\
\hline
\end{tabular}

From the point of view of knowledge of transfusion and transfusion safety, for all questions the percentage of correct answers, varied from $74.47 \%$ for the factors favoring the appearance of anti-erythrocyte immune antibodies, $63.83 \%$ for the antibody present in the plasma of a group A patient, $89.36 \%$ for the plasma corresponding to a group B patient, $68 \%$ for the delay in the return of the patient's transfusion form to the CRTS, $76.60 \%$ for the conditions of plasma thawing, and $46.81 \%$ for the conditioning of the standard platelet concentrate (Table 2).

Table 2: Knowledge of transfusion

\begin{tabular}{|c|c|c|}
\hline Knowledge of basic concepts & $\%$ & Answers \\
\hline \multicolumn{3}{|l|}{$\begin{array}{l}\text { - Factors favoring the appearance of } \\
\text { immune anti-erythrocyte } \\
\text { antibodies: }\end{array}$} \\
\hline Transplant & 30,04 & \\
\hline Vaccination & 21,28 & \\
\hline Transfusion & 74,47 & \\
\hline Infection & 27,66 & \\
\hline Pregnancy & 48,94 & \\
\hline \multicolumn{3}{|l|}{$\begin{array}{l}\text { - The antibody present in the plasma } \\
\text { of a group A subject: }\end{array}$} \\
\hline Anti A & 34,04 & No \\
\hline Anti B & 63,83 & Yes \\
\hline Anti AB & 25,03 & No \\
\hline \multicolumn{3}{|l|}{ - The plasma corresponding to a } \\
\hline $\begin{array}{l}\text { group D } \\
\text { group O }\end{array}$ & 70,21 & No \\
\hline group $\mathrm{AB}$ & 31,91 & Yes \\
\hline group A & 10,64 & No \\
\hline \multicolumn{3}{|l|}{$\begin{array}{l}\text { - Time to return the patient's } \\
\text { transfusion card to the CRTS: }\end{array}$} \\
\hline Less than 24 hours & 68 & Yes \\
\hline More than 24 hours & 6 & No \\
\hline No answer & 26 & \\
\hline \multicolumn{3}{|l|}{ - Conditions of plasma thawing } \\
\hline At room temperature & 76,60 & Yes \\
\hline Under the hot water tap & 8,51 & No \\
\hline In an oven of $37^{\circ} \mathrm{C}$ & 4,26 & No \\
\hline In a water bath at $37^{\circ} \mathrm{C}$ & $\begin{array}{l}4,20 \\
14,89\end{array}$ & No \\
\hline \multicolumn{3}{|l|}{ - Conditioning of the standard } \\
\hline Transport in a refrigerator & 23,40 & Yes \\
\hline Storage at room temperature & 46,81 & Yes \\
\hline Transfused upon receipt & 19,15 & Yes \\
\hline Storage under agitation & & \\
\hline
\end{tabular}

Only $25.53 \%$ did not know that there were measures to prevent or reduce transfusion risks and $8.51 \%$ stated that there were no such measures. At the same time, $72.34 \%$ of the staff stated that hemovigilance is based on transfusion surveillance. For $68.09 \%$ of the participants, reporting and analysis of transfusion events, as well as information to recipients with posttransfusion follow-up and traceability of labile blood products are the main tools for operating a hemovigilance system, followed by prevention of transfusion events with $63.83 \%$ (Table 3 ).

Table 3: Knowledge of transfusion safety

\begin{tabular}{|c|c|}
\hline Knowledge of basic concepts & $\%$ \\
\hline $\begin{array}{l}\text { Participants' knowledge of blood's } \\
\text { transfusion: safety } \\
\text { Yes } \\
\text { No }\end{array}$ & $\begin{array}{l}82,98 \\
17,02\end{array}$ \\
\hline $\begin{array}{l}\text { Storage of the pre-transfusion control card in } \\
\text { the receiver's bed after use and traceability: } \\
\text { Yes } \\
\text { Rarely } \\
\text { No }\end{array}$ & $\begin{array}{l}49 \\
40,43 \\
8,51\end{array}$ \\
\hline $\begin{array}{l}\text { The quality of the transfusion process depends } \\
\text { on: } \\
\text { Professional skills } \\
\text { Organization set up within each department } \\
\text { Quality of information transmission between } \\
\text { these services }\end{array}$ & $\begin{array}{l}72,34 \\
61,70 \\
38,30\end{array}$ \\
\hline $\begin{array}{l}\text { The first step in ensuring the safety of } \\
\text { receivers: } \\
\text { Biological tests on donations }\end{array}$ & 76,60 \\
\hline
\end{tabular}




\begin{tabular}{|c|c|}
\hline $\begin{array}{l}\text { Selection of candidates for blood donation } \\
\text { Physico-chemical inactivation processes }\end{array}$ & $\begin{array}{l}46,81 \\
23,40\end{array}$ \\
\hline \multicolumn{2}{|l|}{ Better transfusion safety requires: } \\
\hline Screening for infections & 68,09 \\
\hline Inactivation of infectious agents & 53,19 \\
\hline \multicolumn{2}{|l|}{$\begin{array}{l}\text { Knowledge of the presence of laws, orders or } \\
\text { circulars governing blood transfusion: }\end{array}$} \\
\hline No & 17,02 \\
\hline Yes & 27,66 \\
\hline Don't know & 53,19 \\
\hline \multicolumn{2}{|l|}{$\begin{array}{l}\text { Main operating tools of a haemovigilance } \\
\text { system }\end{array}$} \\
\hline The traceability of labile blood products & 68,09 \\
\hline Prevention of transfusion incidents & 63,83 \\
\hline
\end{tabular}

According to $93.62 \%$ of the participants, hives appeared first after transfusion, followed by allergic reactions and hyperthermia with $85.11 \%$. However, $82.98 \%$ of participants reported shock and general malaise. While $57.45 \%$ of participants mentioned acute lung edema as a manifestation after transfusion. $80.85 \%$ of the participants stated that immunological and infectious risks were the main risks that could occur during transfusion (Table 4).

Table 4: Transfusion skills and blood safety

\begin{tabular}{|c|c|}
\hline Skills & $\%$ \\
\hline \multicolumn{2}{|l|}{$\begin{array}{l}\text { - Verification of the concordance of the } \\
\text { second RCC and its conservation }\end{array}$} \\
\hline $\begin{array}{l}\text { Put in the refrigerator and check just before } \\
\text { transfusion }\end{array}$ & 17,02 \\
\hline $\begin{array}{l}\text { Check at the same time of the first RCC and } \\
\text { left in the patient's bedside }\end{array}$ & 31,91 \\
\hline $\begin{array}{l}\text { Check at the same time of the first RCC and } \\
\text { put back in the refrigerator }\end{array}$ & 55,32 \\
\hline \multicolumn{2}{|l|}{$\begin{array}{l}\text { - The moment of recording the number of } \\
\text { the transfused unit on the transfusion sheet } \\
\text { Upon receipt of units }\end{array}$} \\
\hline Just before the transfusion & 58 \\
\hline At the end of the transfusion & $\begin{array}{c}36 \\
6\end{array}$ \\
\hline \multicolumn{2}{|l|}{ - Performing the transfusion act } \\
\hline Yes & 95,74 \\
\hline No & 2,3 \\
\hline No answer & \\
\hline \multicolumn{2}{|l|}{$\begin{array}{l}\text { The participants' opinion on the need for } \\
\text { the doctor's intervention at the time of the } \\
\text { transfusion }\end{array}$} \\
\hline Yes & 87 \\
\hline No & 11 \\
\hline \multicolumn{2}{|l|}{ - The transfusion act is performed by the } \\
\hline Doctor & 6 \\
\hline Nurse & 95,74 \\
\hline \multicolumn{2}{|l|}{$\begin{array}{l}\text { - Procedure for what to do when a } \\
\text { transfusion incident occurs }\end{array}$} \\
\hline No & $\begin{array}{l}83 \% \\
15 \%\end{array}$ \\
\hline \multicolumn{2}{|l|}{ - Procedures for reporting transfusion } \\
\hline Yes & 66 \\
\hline No & 32 \\
\hline
\end{tabular}

\begin{tabular}{lc}
\hline No answer & 2 \\
& \\
- The main risks that arise after the & \\
transfusion are & 80,85 \\
Immunological and infectious risks & 25,53 \\
Other risks
\end{tabular}

$27.66 \%$ of the participants knew that there are regulations on transfusion, $53.19 \%$ did not know, and $17.02 \%$ thought that they did not exist. $41 \%$ of the participants had received training in blood transfusion, while 55\% had not had any training in transfusion (Fig. 1).

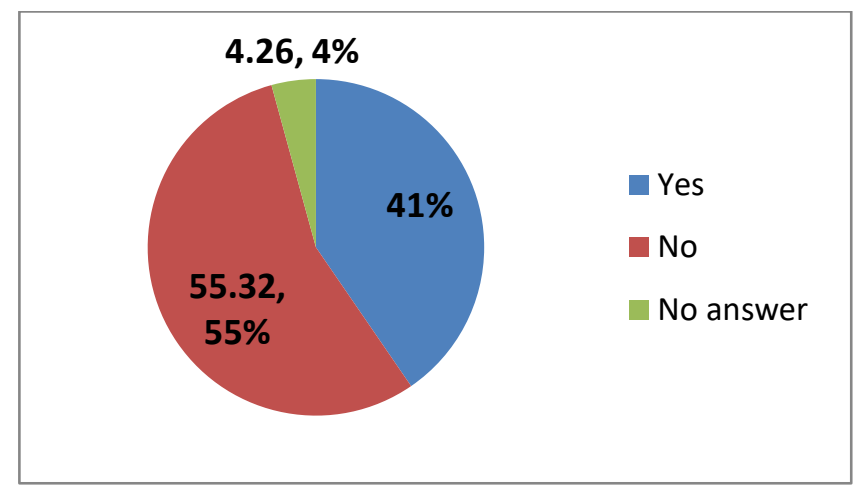

Fig 1: Percentage of professionals who have received training in blood transfusion.

$91.49 \%$ of the participants wished to develop their competence in the field of transfusion and $80.85 \%$ proposed continuing education for the improvement of the transfusion process (Fig.2).

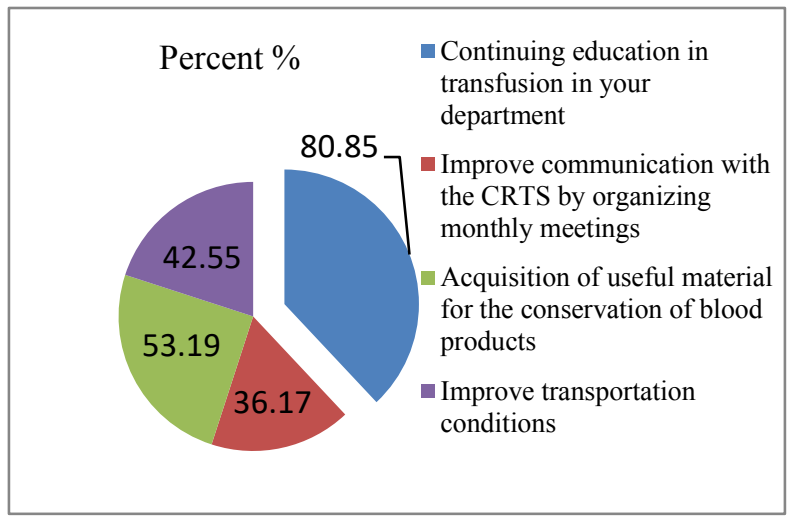

Fig2: Suggestion of professionals to improve the transfusion process at the level of their service 


\section{Discussion}

Transfusion is an indispensable medical act that saves lives and improves others. The health professional's qualification is one of the main components on which the safety of transfusion depends. Indeed, thanks to the knowledge in transfusion and transfusion safety, the health professional will be able or not would be equipped to fight against the transfusion risks that can occur during each transfusion. This study was conducted to assess transfusion and transfusion safety knowledge in a sample of healthcare professionals.

\subsection{Socio-demographic data of participants}

The population in this study is mostly young, with $85.11 \%$ aged between $20-30$ years, which may be due to the fact that in low- and middle-income countries, as is the case here, the overall population is younger [7]. The predominance of female with $68 \%$ against $32 \%$ male in this study can be explained by the large number of female students at academic institutions, which may influence the number of female health professionals [8]. The participants are nurses with 57\%, Diakite reports that nurses are the most dynamic at the level of hospitals [5], also the diversity of their many tasks, in each department of care, we must have more nurses than doctors, such is the case here.

\subsection{Knowledge of transfusion}

From the point of view of transfusion knowledge and safety, it has been reported that the rate of ignorance of $\mathrm{ABO}$ compatibility rules varies between $1.2 \%$ and $15 \%$, which is alarming given that any $\mathrm{ABO}$ incompatibility error remains serious [9]. In this regard, this study raises that the percentages of correct answers for the majority of this category of questions are better, ranging from $74.47 \%$ for the factors favoring the appearance of immune anti-erythrocyte antibodies, $89.36 \%$ on the subject of plasma corresponding to a patient of group B, to 63.83 for the antibody present in the plasma of a subject of group A. All these results found, can be explained by the fact that the lack of experience in the participants of our study, and that in $77 \%$ of the cases have a seniority of less than six years, is substituted by their recent knowledge in transfusion, since up to $41 \%$ of the participants have benefited from training, in the form of a chapter that deals with transfusion within their basic training program. The seniority in the function which is very short here, was raised also in Mali, where $70.9 \%$ of the staff have less than five years of experience and in addition they have not received any training in transfusion, something that may have delayed on their knowledge, which was unknown in $30.3 \%$, yet Mr. Diakité does not find a real link between training and the level of knowledge in blood transfusion [5]. But this result of influence of training on knowledge is in agreement with Gouezec $\mathrm{H}$ et al. who assumed that thanks to refresher training, carried out every two years, the notions on blood products, their indications as well as transfusional accidents could be mastered by the professionals, with respectively $60 \%, 36.8 \%$ and $40 \%$ [10].

In other studies, such as in Iran $22 \%$, Tunisia $15 \%$, Mali $37.6 \%$ between $2 \%$ and $56 \%$ in Saudi and Canada $37 \%$ [4,11,12], basic knowledge about blood transfusion among professionals remains insufficient with more than $37.6 \%$ and unknown in $30.3 \%$ of cases, in general blood transfusion knowledge have been moderate [13-16].

\subsection{Transfusion safety and skills}

The risks related to any transfusion act are unknown by $36.4 \%$ of health professionals [5], in this study $80.85 \%$ of professionals are well aware of these risks, and even report that they are in first infectious or immunological, and up to $83 \%$ against $15 \%$ of the participants have the skills, and even know the measures to be followed in front of such risks and $66 \%$ know how to report them. The approach to be taken before a post transfusion reaction is known by more than $90 \%$ of agents Despite all this, the $40.43 \%$ of our participants who have received training in transfusion, places our participants between those of Gouezec et al with $76 \%$, [10] and those of Diakité with 29.1\% [5].

This knowledge of transfusion safety and this mastery raised in this study may also be due to the fact that $95.74 \%$ of the participants practiced the transfusion act against $2.3 \%$ who did not, and most of the time the transfusion act is performed by nurses (95.74\%). Indeed, the Nurses play an essential role in the blood transfusion process and in the blood transfusion administration [5, 17]. And because of the transfusion risks that they may encounter during or after the transfusion act, $87 \%$ of the participants versus $11 \%$, think that the intervention of the doctors at the time of transfusion is indispensable. Our study reported $85.11 \%$ of hyperthermia and allergic reactions, this result is consistent with Bayraktar et al. witch found that fever and shivering were the most frequently known symptoms of blood transfusion reaction [18, 19].

\subsection{Suggestions}

For the improvement of transfusion act, $53.19 \%$ of the participants suggested improving communication between the transfusion center by organizing monthly meetings, while $80.85 \%$ of the participants suggest continuing education, as our results Aysegul Beyazpinar Kavaklioglu reported that $88 \%$ of the study participants approved continuing education regarding blood and blood products transfusion [19]. Thus, the development of training programs remains an urgent need for healthcare professionals to further improve their knowledge and ensure the safety and quality of blood transfusions [20]. 


\section{Conclusion}

This study revealed heterogeneity among these participants regarding their knowledge, and skills in transfusion. These health professionals participating to in this study have a high motivation to improve their knowledge and develop their skills in the field of transfusion.

In general, the results of this study are better than previous studies, which reported a lack of knowledge about the basics of blood transfusion and safety. However the results of this study cannot be generalized, may be the number of healthcare professionals who participate was limited.

Finally, organization of continuous training in blood transfusion should be regular and improved, supervision of activities in facilities providing health care must be made to ensure better administration of blood products and safety to patients.

\section{Bibliographic references}

1. PF. Lindholm. K. Annen, G.Ramsey. Approaches to minimize infection risk in blood banking and transfusion practice. Infect Disord Drug Targets. 11(1):45-56. (2011). [PubMed] [Google Scholar].

2. NE. MacDonald, SF. O'Brien, G.Delage. Les transfusions et le risque d'infection au Canada: mise à jour pour 2012. Paediatr Child Health; 17(10):e107e111. (2012).

3. G.Suharshi, S.Kanishtha, M. Ruchita and M. Bella. Bacterial Contamination of Donor Blood and Blood Components from a Tertiary Care Hospital in North India. Int.J. Curr. Microbiol.App.Sci.7(07): 1746-1751. (2018).

4. M.Letaief, M. Hassine, I, Bejia, F. Ben Romdhane, K. Ben Salem, and M.S. Soltani, Para Medical Staff Knowledge and Practice Related to the Blood Transfusion Safety. Transfusion Clinique et Biologique,12,25-29(2005).

http://dx.doi.org/10.1016/j.tracli.2005.01.002.

5. M. Diakité, S.I. Diawara, N. Tchiengoua Tchogang, D.Bfofana, et al. Connaissances et attitudes $d u$ personnel médical en matière de transfusion sanguine au Mali. Transfusion Clinique et Biologique, 19, 7477.(2012).http://dx.doi.org/10.1016/j.tracli.2012.01.004

6. Joint Commission International. National Patient Safety Goals (2010). Available at:http://www.jointcommission.org/.

7. N. Dhingra, Les dons de sang volontaires et non rémunérés sauvent des vies, Communiqué de presse 14 juin, Genève. (2011).

8. Annuaire statistique du MAROC, (2010).

9. P.Le Cosquer. Enquête sur les pratiques des médecins anesthésistes réani-mateurs en transfusion sanguine et en hémovigilance. Ann Fr AnesthRéanim; 19:485-91.(2000).

10. H. Gouëzec, P. Jego, P. Bétrémieux, S. Nimubona, I. Grulois. Les indications des produits sanguins labiles et la physiologie de la transfusion en médecine. Transfus Clin Biol.12:169-76.(2005).

11. P.Clark, I. Rennie, and S.Rawlinson, Effect of a Formal Education Programme on Safety of Transfusion. British Medical Journal, 323, 1118-1120. (2001). http://dx.doi.org/10.1136/bmj.323.7321.1118.

12.G. Rock, R. Berger, P. Pinkertn, and B. Fernandes, A Pilot Study to Assess Physician Knowledge in Transfusion Medicine. Transfusion Medicine, 12,125128.(2002).http://dx.doi.org/10.1046/j.1365-

3148.2002.00363.x.

13.K.F.N. da Silva, R.D. Duarte, D.R. Floriano, L.F. Andrade, J.L. Tavares, M.M. dos Santos Félix, M.H. Barbosa. Blood transfusion in intensive care units: Knowledge of the nursing team. Avances en Enfermería, 35, 313-323. (2017).

14.A.Dubey, A. Sonker \& R.K.Chaudhary. Evaluation of healthcare workers' knowledge and functioning of blood centres in north India: A questionnaire based survey. Transfusion and Apheresis Science, 49, 565570. (2013).

15. R.D. Duarte, K.F.N. da Silva, M.M. dos Santos Félix, J.L. Tavares, F.B. Zuffi, \& M.H. Barbosa. Knowledge about blood transfusion in a critical unit of a teaching hospital. Bioscience Journal, 33, 788-798. (2017).

16. V. Rajki, M. Csoka, \& J. Meszaros, Professional knowledge and practice mapping among nurses regarding transfusion therapy: A pilot study on reliability and validity testing. Orvosi Hetilap, 156, 366-378. (2015).

17. K. Vasiliki, Enhancing transfusion safety: Nurse's role. International Journal of Caring Sciences, 4,114119. (2011).

18. Bayraktar, N. Hemşirelerin Kan Transfuzyonuna Yonelik Bilgive Uygulamaları, Hacettepe Universitesi Sağlık Bilimleri Enstitusu,Doktora Tezi. Ankara: 1994.

19. Aysegul Beyazpinar Kavaklioglu, Selma Dagci, Besey Oren. Determination of health workers' level of knowledge about blood transfusion. North Clin Istanbul;4(2):165-172. (2017). doi: 10.14744/nci.2017.41275.

20. M.B. Hijji, E.A. Oweis \& R.S.Dabbour. Measuring knowledge of blood transfusion: A Survey of Jordanian Nurses. American International Journal of Contemporary Research, 2, 77-94. (2012). 